OPEN ACCESS

Edited by:

Lauren Virginia Schnabel, North Carolina State University,

United States

Reviewed by:

Brittany Jean Carr,

The Animal Hospital at Liberty

Highway, United States

David John Argyle,

University of Edinburgh,

United Kingdom

*Correspondence:

Jan H. Spaas

jan.spaas@boehringer-ingelheim.com

Specialty section:

This article was submitted to Veterinary Regenerative Medicine,

a section of the journal

Frontiers in Veterinary Science

Received: 17 February 2021

Accepted: 29 March 2021

Published: 19 May 2021

Citation:

Brondeel C, Pauwelyn G, de Bakker E, Saunders J, Samoy $Y$ and Spaas JH (2021) Review: Mesenchymal Stem

Cell Therapy in Canine Osteoarthritis

Research: "Experientia Docet" (Experience Will Teach Us).

Front. Vet. Sci. 8:668881.

doi: 10.3389/fvets.2021.668881

\section{Review: Mesenchymal Stem Cell Therapy in Canine Osteoarthritis Research: "Experientia Docet" (Experience Will Teach Us)}

\author{
Carlien Brondeel ${ }^{1}$, Glenn Pauwelyn ${ }^{2}$, Evelien de Bakker ${ }^{1}$, Jimmy Saunders ${ }^{1}$, Yves Samoy ${ }^{1}$ \\ and Jan H. Spaas ${ }^{1,2 *}$ \\ 1 Department of Medical Imaging and Orthopedics of Domestic Animals, Faculty of Veterinary Medicine, Ghent University, \\ Merelbeke, Belgium, ${ }^{2}$ Global Stem Cell Technology NV, Part of Boehringer-Ingelheim, Evergem, Belgium
}

Osteoarthritis $(\mathrm{OA})$ is currently an incurable and progressive condition in dogs causing chronic joint pain and possibly increasing disability. Due to the poor healing capacity of cartilage lesions that occur with $\mathrm{OA}$, development of effective therapeutics is difficult. For this reason, current $O A$ therapy is mostly limited to the management of pain and inflammation, but not directed ad disease modification. In the search for a safe and effective OA treatment, mesenchymal stem cells (MSCs) have been of great interest since these cells might be able to restore cartilage defects. The designs of OA studies on MSC usage, however, are not always consistent and complete, which limits a clear evaluation of MSC efficacy. The general study results show a tendency to improve lameness, joint pain and range of motion in dogs suffering from naturally-occurring OA. Assessment of the cartilage surface demonstrated the ability of MSCs to promote cartilage-like tissue formation in artificially created cartilage defects. Immunomodulatory capacities of MSCs also seem to play an important role in reducing pain and inflammation in dogs. It should be mentioned, however, that in the current studies in literature there are specific design limitations and further research is warranted to confirm these findings.

Keywords: mesenchymal stem cell, osteoarthiritis, dog, autologous, allogeneic, xenogeneic

\section{OSTEOARTHRITIS}

\section{Characteristics of Osteoarthritis}

Osteoarthritis $(\mathrm{OA})$ is a commonly seen condition in veterinary medicine, causing chronic pain and increasing disability due to progressive joint degeneration (1-5). Prevalence studies described that $2.5 \%$ of dogs presented to primary practices in the UK with OA and more than $20 \%$ of dogs over 1 year old in the US are affected by OA $(1,3,5)$. Specific breeds (e.g., Labrador, Golden Retriever), castration, advanced age and obesity are suggested to be risk factors of OA development $(1,5,6)$.

Although OA is often diagnosed in older dogs, it is not part of normal aging (4). Contrary to human and feline $\mathrm{OA}$, canine $\mathrm{OA}$ is in general secondary to trauma, including abnormal loading on a normal joint (e.g., joint injury) or normal force on an abnormal joint (e.g., elbow and hip dysplasia) $(1,3,4)$. Osteoarthritis is characterized by osteophyte formation, bone remodeling, changes in peri-articular tissue and synovitis $(2,3)$. Nevertheless, the main feature of $\mathrm{OA}$ is cartilage damage. When the cartilage homeostasis is disturbed, chondrocytes become "activated" and produce inflammatory mediators which are able to stimulate progression 
of cartilage damage and adjacent joint tissue alterations, establishing a vicious cycle of joint deterioration and worsening $\mathrm{OA}(3,7)$.

Unfortunately, due to relative avascularity and therefore the lack of systemic regulation, the repair capacity of cartilage is very poor $(2,3)$. For this reason, OA is a life-long progressive disease that currently cannot be cured (4). The lack of an OA cure necessitates management to reduce pain and inflammation, to restore normal cartilage and joint function and to prevent further damage (2). Many therapeutics are available which all target different aspects of OA.

\section{Osteoarthritis Management}

Pharmacologic analgesia is probably the most common component of OA management. Non-steroidal antiinflammatory drugs (NSAIDs), tramadol and gabapentin are frequently used to reduce the pain and inflammation. However, a profound patient selection and follow-up is indicated since potential side effects are well-known $(4,5)$. Intra-articular (IA) administration of hyaluronic acid (HA) and platelet rich plasma (PRP) are effective to improve joint pain and mobility and to influence healing of bone, tendon, muscle and ligament, respectively (5, 8-11). It is also described that PRP induces chondrogenesis, is able to increase anti-inflammatory mediators and decrease pro-inflammatory mediators (11). Although effective to manage OA related complaints, HA and PRP are not able to cure cartilage damage. Since cartilage protection is a difficult task of OA management, various food supplementation products, frequently based on chondroitin, glucosamine, methylsulfonylmethane (MSM), glycosylated undenaturated type II collagen and omega-3 fatty acids, were developed. These nutraceuticals might act as "building blocks" of cartilage and reducers of inflammation. $(4,5,12,13)$. Unfortunately, except for undenaturated type II collagen and omega-3 fatty acids, scientific evidence on supplement efficiency is scares $(4,12-15)$. Alternative $\mathrm{OA}$ management includes physical rehabilitation and body weight control. Physiotherapeutic modalities and exercises reduce pain and improve movement and joint function $(4,5)$. A reduction of body weight decreases joint loading and the risk of joint injury $(4-7,12)$. Although this kind of OA management is simple, good results can only be achieved with owner compliance.

\footnotetext{
Abbreviations: AD-MSCs, adipose tissue-derived MSCs; BVF, bone volume fraction; COX, cyclooxygenase; CT, computer tomography; ECM, extracellular matrix; ePB-MSCs, equine peripheral blood derived mesenchymal stem cells; EVs, extracellular vesicles; GAG, glycosaminoglycan; GFP, green fluorescent protein; HA, hyaluronic acid; IA, intra-articular; IL, interleukin; iNOS, inducible nitric oxide synthase; iPSCs, induced pluripotent stem cells; IFN, interferon; IV, intravenous; $\mathrm{MHC}$, major histocompatibility complex; MRI, magnetic resonance imaging; MSCs, mesenchymal stem cells; MSM, methylsulfonylmethane; NO, nitric oxide; NSAIDs, non-steroidal anti-inflammatory drugs; OA, osteoarthritis; PARP, poly adenosine diphosphate-ribose polymerase; PCR, polymerase chain reaction; PRP, platelet rich plasma; PVF, peak vertical force; ROM, range of motion; RT, repeated treatment; SEM, scanning electron microscopy; SOX, sexdetermining region Y-related high mobility group-box; TENS, transcutaneous electrical nerve stimulation; TNF, tumor necrotic factor; TGF- $\beta 1$, transforming growth factor- $\beta 1$; US, ultrasound; VEGF, vascular endothelial growth factor; VI, vertical impulse.
}

\section{Upcoming Importance of Mesenchymal Stem Cells in the Osteoarthritis Research Field}

Since current OA management has its limitations and is not able to reverse cartilage damage, new and promising research areas have been explored. Biological therapies based on mesenchymal stem cells (MSCs) have become of great interest in both human and veterinary OA research. In contrast to embryonic stem cells, MSCs are derived from adult tissue (16). Being unspecialized and able to differentiate into multiple cell lineages, including chondrocytes, these adult stem cells have the capacity to repopulate cartilage defects $(2,17)$. Reduction of local and systemic inflammation can be enabled by the MSCs' immunomodulatory capabilities $(2,18,19)$. Furthermore, MSCs apply paracrine signaling which stimulate local repair cells that may contribute to cartilage healing $(2,18-20)$. MSCs have also been shown to possess homing capacities, meaning they can be recruited, both locally and systemically, to sites of tissue injury (21).

In human research, study results strongly suggest that MSC therapy is effective in relieving pain and improving joint function in patients suffering from OA. Especially the effect on knee OA has been investigated thoroughly (22-24). Moreover, since no obvious adverse effects are described, MSC use in humans might be a safe and effective alternative for current OA management therapies $(22,23)$. In veterinary medicine, being humans' closest companions and susceptible to OA, dogs and horses have been the main focus of MSC research. As in human OA research, study results are promising, providing evidence that MSC treatments may be safe and effective $(25,26)$. However, both human and veterinary studies focused on the efficacy and safety of MSCs as an OA therapy, many features of MSCs are not yet completely understood. A growing knowledge about MSC capabilities may provide the solution for both human and veterinary patients suffering from $\mathrm{OA}$ by slowing down disease progression or even reversing the damage and restoring full function.

\section{Varieties of Mesenchymal Stem Cells in Veterinary Research}

In mesenchymal stem cell research, three types of MSCs can be differentiated: autologous, allogeneic and xenogeneic MSCs. When a patient receives its own MSCs, these MSCs are autologous. Allogeneic MSCs refer to MSCs derived from a donor animal of the same species as the receiving animal. Application of donor MSCs of a different species is called xenogeneic. Autologous derived MSCs are preferably used in veterinary studies since these cells are immunologically compatible with the receiving patient (27). Also, use of autologous MSCs does not involve donor animal harvesting and so does not imply ethical issues $(28,29)$. Harvesting every single patient and producing autologous MSCs, however, is a time consuming and challenging task for most veterinary practices. For this reason, many research groups investigated MSCs derived from donor animals as an attractive alternative. Allogeneic and xenogeneic MSCs are "ready to treat" which means that they can be prepared and stored in commercial quantities (30). In donor-derived MSC studies, 
allogeneic MSCs are preferred since they are expected to have higher donor-host compatibility than xenogeneic MSCs (30). Nevertheless, some canine studies did investigate the application of xenogeneic equine and porcine MSCs $(31,32)$. Additional features of xenotransplantation are absence of canine-specific transferable pathogens and a higher culture capacity of equine compared to canine MSCs (19).

The possibility of allogeneic and even xenogeneic MSC usage was clarified by several canine and equine studies which described MSCs to be "immune privileged." It is proposed that this interesting MSC feature is the consequence of an absent major histocompatibility complex (MHC) class II expression on its cell surface $(27,33)$. An absent MHC class II expression is favorable in allogeneic and xenogeneic circumstances since these molecules initiate an antigen-specific immune response by presenting extracellular pathogens to $\mathrm{CD} 4^{+} \mathrm{T}$ cells $(34)$. More recent studies, however, described that MHC class II could be up-regulated in vitro when presenting the MSCs in inflammatory environments making them recognizable for the host's immune system. For this reason, this needs to be assessed before clinical use $(27,33)$. Others described the possibility of allogeneic and xenogeneic usage to be a consequence of immunomodulatory capabilities of MSCs which reduces the relevance of a cellular immune response after potential MHC upregulation. In addition, suppression of the host's immunological reaction toward donor MSCs might enable allo- and xenotransplantation (30).

To apply autologous, allogeneic or xenogeneic MSCs as a therapeutic tool, cells need to be harvested from tissue and cultured in laboratory conditions. In canine OA research, the use of a variety of MSC sources is described, such as adipose tissue $(28,32,35-51)$, bone marrow (52-58), synovium (59), dental pulp (60), fetal adnexa (61), umbilical cord $(62,63)$ and peripheral blood (31). Currently, adipose tissue and bone marrow seem to be the most popular MSC sources. The popularity of adipose tissue-derived MSCs (AD-MSCs) can be attributed to an easy accessibility and expansion in culture $(29,64,65)$.

The aim of the current review article is to provide a clear overview of currently reported canine OA research on MSC application, with a main focus on study execution, efficacy and safety results. Special attention is given to the distinctive features and challenges of autologous, allogeneic and xenogeneic MSC use.

\section{MESENCHYMAL STEM CELL APPLICATION IN CANINE OSTEOARTHRITIS RESEARCH}

\section{Types of Canine Osteoarthritis Research on Mesenchymal Stem Cells}

Current canine OA research on auto-, allo-, and xenotransplantation of MSCs, can be subdivided into two study types (based on the study population) (Figure 1). The first type and majority of canine OA studies include companion animals suffering from naturally-occurring OA (Tables 1, 2, 3) $(28,31,32,35-50,60-62)$. In studies of a second type, joint damage is induced in purpose-bred dogs in order to investigate the potential of MSCs to heal cartilage (Tables 4, 5) (51-59, 63).

Studies evaluating naturally-occurring $\mathrm{OA}$ have an advantage over model-based studies since they evaluate the effect of MSCs on a real world (field) condition (28, 31, 32, 35-50, 60-62). Nevertheless, establishing natural OA studies often encounters some difficulties. Since, in this type of study, the targeted population consists of owned animals, patient recruitment is challenging and study populations are often rather small $(31,32$, $37,40-42,45,49,50,60)$. Also, a control group is frequently missing because owners want their dog to actually be treated (32, 35, 37, 39, 43, 45, 60). Moreover, OA affected dogs often have problems in multiple joints and the severity of OA can differ, which may complicate study outcome interpretation (62).

In studies based on OA models, cartilage or cranial cruciate ligament defects are created surgically in joints of purpose-bred dogs before MSC administration (51-59, 63). In some studies, however, MSCs are administered during or immediately after surgery, which might not adequately represent the effect on chronic OA $(52,53,56-58)$. Compared to studies with client owned animals, model based studies can easily include control groups and provide the opportunity to apply a wider variety of research tools (e.g., histopathology) (32). Unfortunately, to enable histo- and pathologic examinations, which are essential for thorough safety assessment, animal sacrifice is sometimes required.

\section{Mesenchymal Stem Cell Administration in Osteoarthritis Studies}

Several administration routes have been investigated to administer MSCs to an OA affected or a purpose-bred dog (Figure 1). Mostly, MSCs are administrated directly into the affected joint by an IA injection $(28,31,32,35-39,41,42,44-$ $51,54,55,59-63)$. However, since MSCs are known to have homing capacities, some studies investigated the effectiveness of other administration routes $(21,40,43,44)$ such as: intravenous (IV) administration $(43,44)$ and administration via acupuncture points (40). Systemic delivery may be advantageous since these MSCs may evoke a greater interaction with the immune system than local delivered MSCs $(43,66)$. MSCs seem to be able to enhance white blood cell activity, differentiation and migration to lesion sites (66). Although further research is indicated to clarify the exact mode of action, such a systemic interaction with the immune system may lead to reduced inflammation at multiple affected joints in the body $(43,66)$. Moreover, IV administration can make MSC based treatments more accessible for primary practice. Acupuncture point administration might, according to a study in rats and dogs, enhance blood flow and increase the level of vascular endothelial growth factor (VEGF), transforming growth factor (TGF)- $\beta 1$ and nitric oxide (NO), improving angiogenesis and arteriogenesis (40,67). Other studies described the deposition of MSCs into the joint using a scaffold. Scaffolds are tissue-engineered constructs, consisting of a distinct cartilage and bone layer, which can be transplanted into large osteochondral defects to offer a template for new tissue formation and organization. Prior to transplantation, MSCs are 


\section{MESENCHYMAL STEM CELL TREATMENT IN CANINE OA}

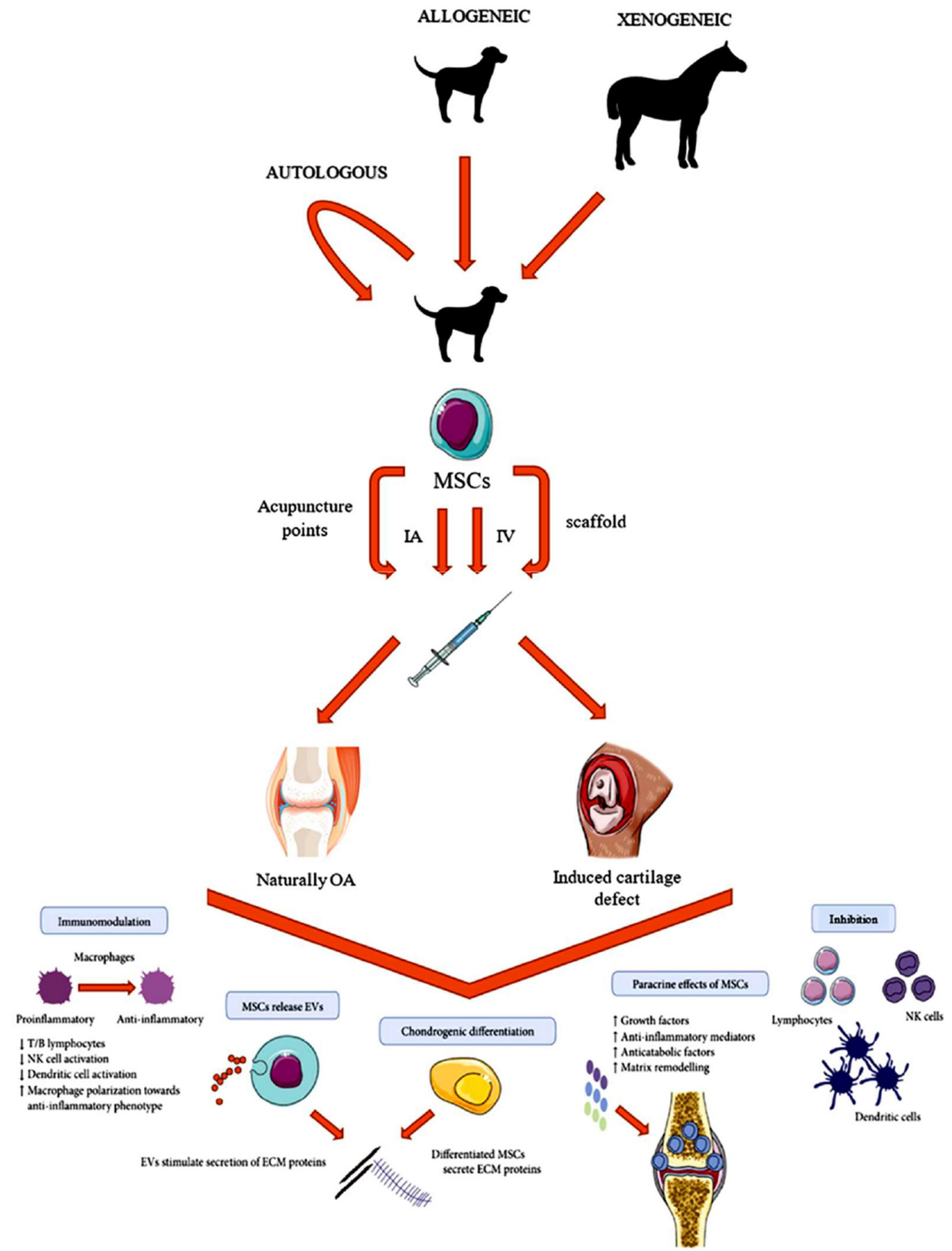

FIGURE 1 | Schematic overview of mesenchymal stem cell administration in canine osteoarthritis studies [Modified from Lo Monaco et al. (20)]. 
TABLE 1 | Chronologic presentation of studies on naturally occurring OA applying autologous MSC.

\begin{tabular}{|c|c|c|c|c|c|c|c|c|c|}
\hline Author & $\begin{array}{c}\# \\
\text { Patients }\end{array}$ & Groups/treatment & $\begin{array}{l}\text { OA } \\
\text { location }\end{array}$ & $\begin{array}{l}\text { MSC } \\
\text { source }\end{array}$ & $\begin{array}{l}\text { Injection } \\
\text { site }\end{array}$ & $\begin{array}{c}\text { Dosage } \\
\text { MSC (cells) }\end{array}$ & \# Injections & Outcome & $\begin{array}{l}\text { Side effects } \\
\text { MSCs }\end{array}$ \\
\hline Black et al., (28) & 21 & $\begin{array}{l}\text { MSC: not } \\
\text { specified } \\
\text { Control: not } \\
\text { specified }\end{array}$ & hip & fat & $\mathrm{IA}$ & $4.2-5 \times 10^{6}$ & 1 & + & No \\
\hline Black et al., (35) & 14 & MSC: 14 & elbow & fat & $\mathrm{IA}$ & $3-5 \times 10^{6}$ & 1 & + & No \\
\hline $\begin{array}{l}\text { Guercio et al., } \\
\text { (37) }\end{array}$ & 4 & $\begin{array}{l}\text { MSC + HA: } 2 \\
\text { MSC + PRP: } 2\end{array}$ & elbow & fat & $\mathrm{IA}$ & $3-5 \times 10^{6}$ & 1 & + & No \\
\hline Yoon et al., (50) & 1 & $\begin{array}{l}\text { MSC + surgery + } \\
\text { HA: } 1\end{array}$ & stifle & fat & IA & $1 \times 10^{6}$ & 1 & + & No \\
\hline Vilar et al., (48) & 13 & $\begin{array}{l}\text { MSC + PRP: } 8 \\
\text { Control: } 5\end{array}$ & hip & fat & $\mathrm{IA}$ & $15 \times 10^{6}$ & 1 & + & No \\
\hline Cuervo et al., (36) & 35 & $\begin{array}{l}\text { MSC: } 18 \\
\text { PRP: } 17\end{array}$ & hip & fat & $\mathrm{IA}$ & $30 \times 10^{6}$ & 1 & + & No \\
\hline Nicpon et al., (42) & 12 & $\begin{array}{l}\text { MSC: } 8 \\
\text { Control: } 4\end{array}$ & elbow & fat & $\mathrm{IA}$ & $1.5 \times 10^{6}$ & 1 & + & No \\
\hline Vilar et al., (46) & 15 & $\begin{array}{l}\text { MSC: } 10 \\
\text { Control: } 5\end{array}$ & hip & fat & $\mathrm{IA}$ & $15 \times 10^{6}$ & 1 & + & Yes (1 dog) \\
\hline $\begin{array}{l}\text { Mohoric et al., } \\
(41)\end{array}$ & $\begin{array}{l}10(20 \\
\text { stifles })\end{array}$ & $\begin{array}{l}\text { MSC: } 10 \text { stifles } \\
\text { Control: } 10 \text { stifles }\end{array}$ & stifle & fat & IA & $2-3 \times 10^{6}$ & 1 & + & No \\
\hline Vilar et al., (47) & 15 & $\begin{array}{l}\text { MSC: } 10 \\
\text { Control: } 5\end{array}$ & hip & fat & $\mathrm{IA}$ & $15 \times 10^{6}$ & 1 & + & No \\
\hline $\begin{array}{l}\text { Srzentic Drazilov } \\
\text { et al., (45) }\end{array}$ & 10 & MSC: 10 & $\begin{array}{l}\text { Different } \\
\text { joints }\end{array}$ & fat & $\mathrm{IA}$ & $>15 \times 10^{6}$ & 1 & + & No \\
\hline
\end{tabular}

seeded on these scaffolds $(52,56,57)$. Based on a matched-pair study by Kim et al. (68), MSC administration on a scaffold was more efficient to improve clinical and arthroscopic outcomes in humans with stifle OA than MSC administration via IA injection (68). However, since the wide variety of described scaffold types, the finding of Kim et al. (68) should not be generalized.

In current OA research on MSCs, specific dose determination and safety studies are currently lacking and so the amount of MSCs and frequency of administration is very variable between publications. Doses are often based on the knowledge and experience of the authors, the applied tissue, the laboratory conditions, the amount of passages and viable cells. In autologous studies evaluating naturally-occurring OA, AD-MSCs dose varied from $1 \times 10^{6}$ to $>15 \times 10^{6}$ cells administered with a single IA injection $(28,35-37,41,42,45-48,50)$. Doses of single and repeated IA, IV and acupuncture point injections of allogeneic MSC to OA affected dogs ranged from $0.2 \times 10^{6}$ cells to 2 $\times 10^{6}$ cells per kilogram bodyweight $(38-40,43,44,49,60-$ 62). In xenogeneic naturally-occurring OA studies, single IA injections of $5 \times 10^{6}$ porcine MSCs in canine stifle joints (32) and $1 \times 10^{6}$ equine MSCs in canine elbow joints (31) were performed. In model-based autologous studies, the amount of MSCs administered by a single IA injection or implantation ranged from $5 \times 10^{5}$ to $5 \times 10^{7}$ cells $(53,55,56,58,59)$. To transfer the MSCs to the defect side in allogeneic studies, up to $5 \times 10^{7}$ MSCs were seeded on a scaffold $(52,57)$ and $1 \times 10^{6}$ to 1 $\times 10^{7}$ MSCs were injected IA (up to four injections) $(51,54,63)$.

Within the field of MSC research, MSCs are often characterized before administration. Next to the standard measures such as cell count, viability, sterility and cell adhesion, MSCs can be characterized using different cell surface markers, trilineage differentiation and morphology characterization. However, the majority of canine OA studies using MSCs did not perform a complete characterization of their applied cells. In most studies on naturally-occurring OA in dogs, at least two of the earlier mentioned analysis/analyses of MSC characteristics were lacking. The types of lacking analyses differed greatly between studies, but in general cell morphology and proliferation were the least evaluated MSC characteristics. An analyzation of the cell surface markers was described most commonly $(28,32,35-50,60-62)$. Daems et al. (31), who investigated the use of xenogeneic MSCs in dogs with naturally occurring $\mathrm{OA}$, presented the most complete set of MSC characterizing analyses (31). In canine model-based OA studies on MSC usage, the lack of performed MSC characterizing analyses was even more pronounced than in naturally-occurring OA studies $(51-59,63)$. In most of these studies, only an evaluation of cell adhesion and cell surface markers was performed $(51,53,54,63)$. This insufficient evaluation of MSC characteristics is an important limitation in current canine MSC research, making proper data interpretation and comparison challenging. To improve future studies, MSC characterizing analyses need to become standardized.

Besides the MSCs, some research groups administrated additional products and evaluated their possible MSC potentiating effect in OA affected joints. Typically, the additional products were $\mathrm{HA}(37,39,49,50,54,58,59)$ or PRP $(36,37,48,51,53)$. A comparison between the clinical 
TABLE 2 | Chronologic presentation of studies on naturally occurring OA applying allogeneic MSC.

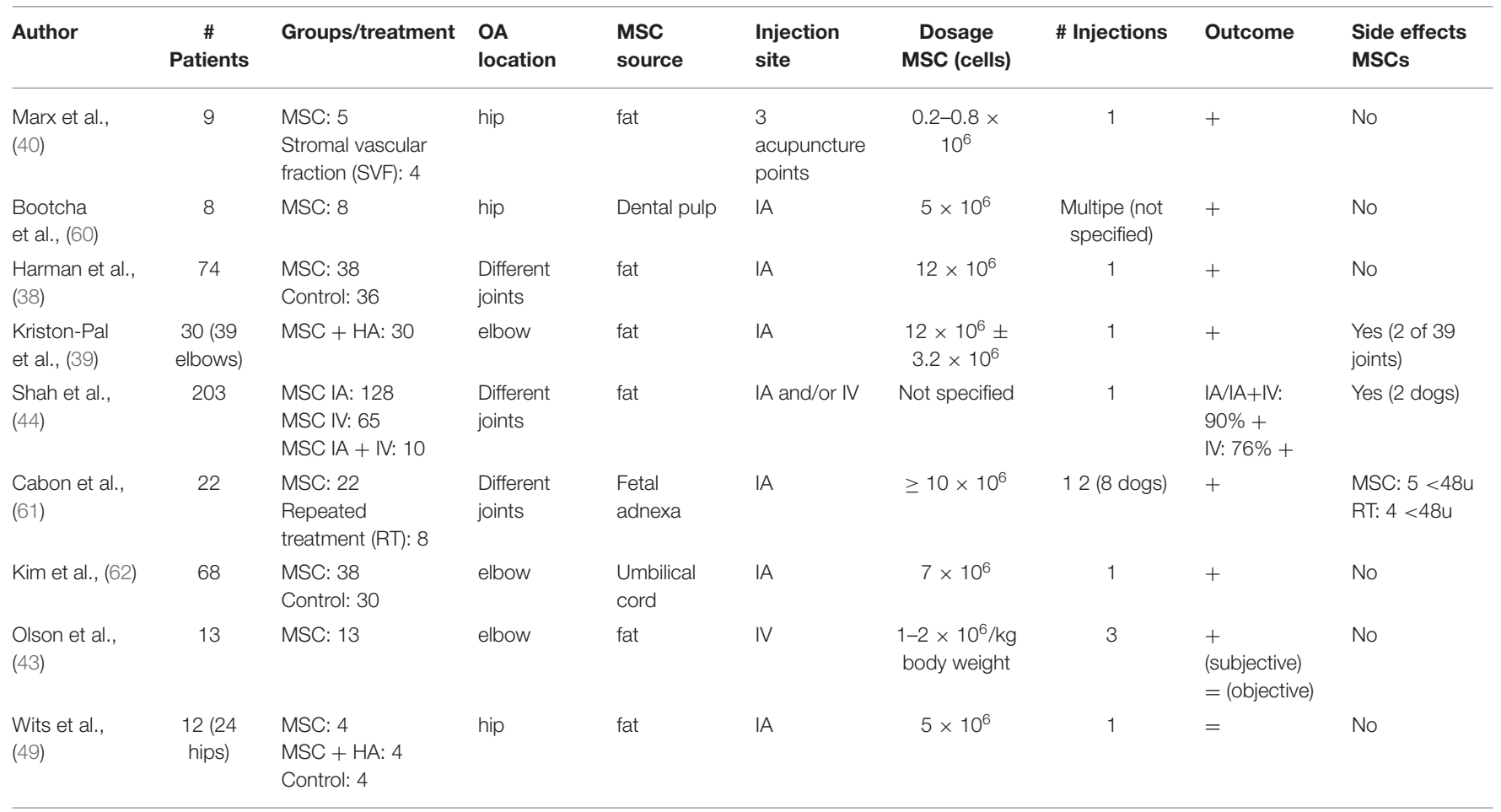

TABLE 3 | Chronologic presentation of studies on naturally occurring OA applying xenogeneic MSC.

\begin{tabular}{|c|c|c|c|c|c|c|c|c|c|}
\hline Author & $\begin{array}{c}\# \\
\text { Patients }\end{array}$ & Groups/treatment & $\begin{array}{l}\text { OA } \\
\text { location }\end{array}$ & $\begin{array}{l}\text { MSC } \\
\text { source }\end{array}$ & $\begin{array}{l}\text { Injection } \\
\text { site }\end{array}$ & $\begin{array}{c}\text { Dosage } \\
\text { MSC (cells) }\end{array}$ & \# Injections & Outcome & $\begin{array}{l}\text { Side effects } \\
\text { MSCs }\end{array}$ \\
\hline Tsai et al., (32) & 3 & MSC: 3 & stifle & Porcine fat & IA & $5 \times 10^{6}$ & 1 & + & No \\
\hline
\end{tabular}

effect of solo administration of additional products and MSCs was, although interesting, only made by three research groups $(36,54,59)$.

\section{Mesenchymal Stem Cell Efficacy Evaluation in Osteoarthritis Studies}

Evaluation of MSC efficacy as an OA therapy was conducted by a wide array of research tools. In general, studies evaluating naturally-occurring $\mathrm{OA}$ were evaluated orthopedically based on lameness, pain at joint manipulation and/or range of motion (ROM) $(28,31,32,35,36,38-42,44,45,49,60-62)$. Additionally, assessment of the effect of an MSC treatment on OA affected dogs may include owner questionnaires/evaluations $(28,31,32,35-$ $41,43,47,60-62)$, medical imaging $(31,32,36,41,42,49,60)$, synovial fluid analyses $(31,41-43)$ and objective gait analysis by force or pressure plate $(31,32,43,46-48,62)$. In most naturally-occurring OA studies, MSC safety was also assessed $(31,32,36,38,42,43,49,61,62)$. By using purpose-bred dogs instead of client-owned dogs, model-based OA studies allowed evaluation of MSC treatments with macroscopic and/or microscopic joint assessments (51-59). Additional applied research techniques/tools described in autologous and allogeneic model-based studies were: lameness evaluations $(51,55)$, medical imaging $(54,57,63)$, biochemical evaluations (56), biomechanical evaluations $(51,56,57)$, micro-computer tomography (CT) (52, 56 , 57), green fluorescent protein (GFP)-labeling for homing assessment (55), real-time polymerase chain reaction (PCR) (51), spectrophotometry (51), scanning electron microscopy (SEM) (63) and blood analyses (63).

\section{STUDY OUTCOMES}

\section{Lameness and Joint Function}

Study outcomes based on lameness, pain at joint manipulation and/or range of motion were favorable for all MSC types, sources and administration routes, and in both naturally-occurring $\mathrm{OA}$ 
TABLE 4 | Chronologic presentation of model based studies applying autologous MSC.

\begin{tabular}{|c|c|c|c|c|c|c|c|c|c|c|}
\hline Author & $\begin{array}{c}\# \\
\text { Patients }\end{array}$ & Groups/treatment & $\begin{array}{l}\text { Type } \\
\text { defect }\end{array}$ & $\begin{array}{l}\text { Location } \\
\text { cartilage } \\
\text { defect }\end{array}$ & $\begin{array}{l}\text { MSC } \\
\text { source }\end{array}$ & Injection site & $\begin{array}{c}\text { Dosage } \\
\text { MSC (cells) }\end{array}$ & $\begin{array}{l}\text { \# Admini- } \\
\text { strations }\end{array}$ & Outcome & $\begin{array}{l}\text { Side effects } \\
\text { MSCs }\end{array}$ \\
\hline $\begin{array}{l}\text { Miki et al., } \\
\text { (59) }\end{array}$ & $\begin{array}{l}24 \text { (48 } \\
\text { stifles) }\end{array}$ & 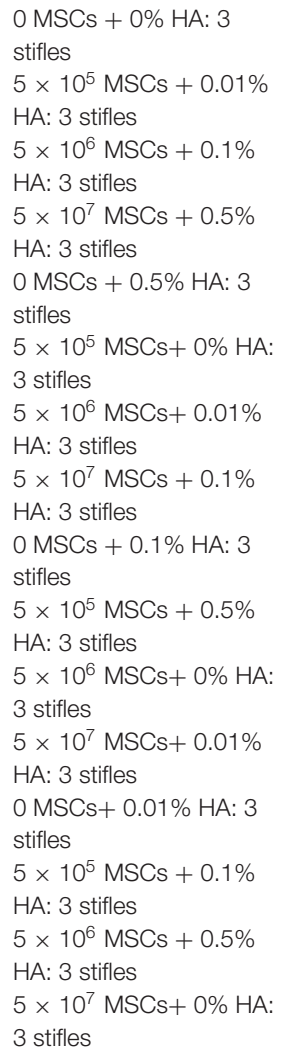 & $\begin{array}{l}\text { Partial } \\
\text { thickness } \\
\text { cartilage }\end{array}$ & $\begin{array}{l}\text { Med. } \\
\text { condyle } \\
\text { femur }\end{array}$ & synovium & $\mathrm{IA}$ & $\begin{array}{l}\text { See column } \\
\text { group/treatme }\end{array}$ & $\begin{array}{c}1 \\
\text { ents }\end{array}$ & + & No \\
\hline $\begin{array}{l}\text { Yamasaki } \\
\text { et al., (58) }\end{array}$ & $\begin{array}{l}15 \text { (30 } \\
\text { stifles) }\end{array}$ & $\begin{array}{l}\text { MSC + serum + HA: } 15 \\
\text { stifles } \\
\text { Serum + HA: } 15 \text { stifles }\end{array}$ & $\begin{array}{l}\text { Full } \\
\text { thickness } \\
\text { cartilage }\end{array}$ & $\begin{array}{l}\text { Patellar } \\
\text { groove }\end{array}$ & $\begin{array}{l}\text { Bone } \\
\text { marrow }\end{array}$ & $\begin{array}{l}\text { Direct } \\
\text { implantation } \\
\text { in defect }\end{array}$ & $\begin{array}{c}0.2-2.8 \times \\
10^{7}\end{array}$ & 1 & + & No \\
\hline $\begin{array}{l}\text { Kazemi et al., } \\
2017 \text { (53) }\end{array}$ & $\begin{array}{l}12(24 \\
\text { stifles) }\end{array}$ & $\begin{array}{l}\text { MSC + PRF: } 12 \text { stifles } \\
\text { Control: } 12 \text { stifles }\end{array}$ & $\begin{array}{l}\text { Osteo- } \\
\text { chondral }\end{array}$ & $\begin{array}{l}\text { Med. } \\
\text { condyle } \\
\text { femur }\end{array}$ & $\begin{array}{l}\text { Bone } \\
\text { marrow }\end{array}$ & $\begin{array}{l}\text { Direct } \\
\text { implantation } \\
\text { in defect }\end{array}$ & $1 \times 10^{6}$ & 1 & + & No \\
\hline
\end{tabular}

and model based studies $(28,31,32,35-42,44-48,50,51,55$, 60-62). For example, after a single IA injection of autologous adipose tissue-derived MSCs to $10 \mathrm{OA}$ affected dogs, significant improvement of lameness and ROM up to 4 years posttreatment was described (45). Compared to IA administration, studies on allogeneic adipose tissue-derived MSCs showed IV administration to be clinically less satisfying $(43,44)$. In Australia, allogeneic adipose tissue-derived MSCs have been commercially available since 2010 as IA and IV treatmentsfor dogs suffering from OA. Shah et al. (44) reported these treatment results and showed a higher percentage of dogs to have a good to excellent quality of life (based on pain, mobility and daily activity) after IA or combined IA-IV treatment $(\sim 90 \%)$ than after IV treatment alone (76\%) (44). Olsen et al. (43) reported improvement of client-specific outcome measures, however, objective outcome measures did not confirm these results (43). One study on allogeneic adipose tissue-derived MSCs described clinical improvement after acupuncture point injections in four of five dogs suffering from hip OA (40). Addition of PRP and HA to MSC treatments was reported to have a positive effect on study outcomes $(37,39,49,50)$. Nevertheless, only one study made a comparison of MSC treatment with and without 
TABLE 5 | Chronologic presentation of model based studies applying allogeneic MSC.

\begin{tabular}{|c|c|c|c|c|c|c|c|c|c|c|}
\hline Author & $\begin{array}{c}\text { \# } \\
\text { Patients }\end{array}$ & $\begin{array}{l}\text { Groups/ } \\
\text { treatment }\end{array}$ & $\begin{array}{l}\text { Type } \\
\text { defect }\end{array}$ & $\begin{array}{l}\text { Location } \\
\text { cartilage } \\
\text { defect }\end{array}$ & $\begin{array}{l}\text { MSC } \\
\text { source }\end{array}$ & Injection site & $\begin{array}{c}\text { Dosage } \\
\text { MSC (cells) }\end{array}$ & $\begin{array}{l}\text { \# Admini- } \\
\text { strations }\end{array}$ & Outcome & $\begin{array}{l}\text { Side effects } \\
\text { MSCs }\end{array}$ \\
\hline $\begin{array}{l}\text { Duan et al., } \\
\text { (52) }\end{array}$ & $\begin{array}{l}12(24 \\
\text { stifles) }\end{array}$ & $\begin{array}{l}\text { MSC + scaffold: } 8 \\
\text { stifles } \\
\text { Scaffold: } 8 \text { stifles } \\
\text { Control: } 8 \text { stifles }\end{array}$ & $\begin{array}{l}\text { Osteo- } \\
\text { chondral }\end{array}$ & Patellar groove & $\begin{array}{l}\text { Bone } \\
\text { marrow }\end{array}$ & $\begin{array}{l}\text { Implantation } \\
\text { with scaffold }\end{array}$ & $1 \times 10^{4}$ & 1 & + & No \\
\hline $\begin{array}{l}\text { Qiang et al., } \\
\text { (57) }\end{array}$ & $\begin{array}{l}12(24 \\
\text { hips) }\end{array}$ & $\begin{array}{l}\text { MSC + scaffold: } \\
12 \text { hips } \\
\text { Control: } 12 \text { hips }\end{array}$ & $\begin{array}{l}\text { Osteo- } \\
\text { chondral }\end{array}$ & Femoral head & $\begin{array}{l}\text { Bone } \\
\text { marrow }\end{array}$ & $\begin{array}{l}\text { Implantation } \\
\text { with scaffold }\end{array}$ & $\begin{array}{l}\text { Seeded with } \\
5 \times 10^{7} / \mathrm{mL}\end{array}$ & 1 & - & No \\
\hline Yun et al., (51) & 24 & $\begin{array}{l}\text { MSC: } 6 \\
\text { PRP: } 6 \\
\text { MSC + PRP: } 6 \\
\text { Control: } 6\end{array}$ & $\begin{array}{l}\text { Cranial } \\
\text { cruciate } \\
\text { ligament }\end{array}$ & / & fat & $\mathrm{IA}$ & $1 \times 10^{7}$ & 4 & + & No \\
\hline Li et al., (54) & $\begin{array}{l}24(48 \\
\text { stifles) }\end{array}$ & $\begin{array}{l}\text { MSC + HA: } 8 \\
\text { HA: } 8 \\
\text { Control: } 8\end{array}$ & $\begin{array}{l}\text { Partial } \\
\text { thickness } \\
\text { cartilage }\end{array}$ & $\begin{array}{l}\text { Bilateral condyle } \\
\text { femur + patellar } \\
\text { groove }\end{array}$ & $\begin{array}{l}\text { Bone } \\
\text { marrow }\end{array}$ & $\mathrm{IA}$ & $1 \times 10^{7}$ & 1 & + & No \\
\hline $\begin{array}{l}\text { Zhang et al., } \\
\text { (63) }\end{array}$ & 8 & $\begin{array}{l}\text { MSC: } 4 \\
\text { Control: } 4\end{array}$ & cartilage & $\begin{array}{l}\text { Condyle femur + } \\
\text { patella }\end{array}$ & $\begin{array}{l}\text { Umbilical } \\
\text { cord }\end{array}$ & IA & $1 \times 10^{6}$ & 2 & + & No \\
\hline
\end{tabular}

additional product (49). Wits et al. showed a greater/earlier improvement of lameness and pain at joint manipulation after combined IA administration of allogeneic adipose tissue-derived MSCs and HA than after solo IA administration of MSCs (49). The difference in effect of additional or solo administration of HA or PRP was addressed by three research groups. Two model based studies describe a better cartilage repair after combined IA administration of autologous synovium and allogeneic bone marrow derived MSCs and HA than after HA alone (54, 59). A study that investigated the joint function after a single IA injection of autologous adipose tissue-derived MSCs and a single IA injection of PRP found enhanced joint mobility and functionality for both products. For these parameters, however, the effect of PRP was less pronounced or did not last as long as the effect of the MSCs (36).

Gait analyses based on force or pressure plate enables objective evaluation of a dog's lameness and limb function. Nevertheless, only a few research facilities studying the effect of autologous, allogeneic and xenogeneic MSCs evaluating naturally-occurring OA were equipped with a force or pressure plate $(31,32$, 43, 46-48). The objective gait evaluations, however, did not always support clinical lameness exam outcomes. For example, Vilar et al. $(46,47)$. demonstrated significant improvement of mean peak vertical force (PVF) and vertical impulse (VI) values within the first 3 months after solo IA adipose tissuederived MSC treatment $(46,47)$. Despite subjective assessment showing improvement, the dogs returned to the initial lameness state 6 months post-treatment (47). Others did not report any significant change in gait evaluation $(31,32,43,62)$. One study on autologous adipose tissue-derived MSCs reported a reduced lameness based on force plate analyses after a combined MSC and PRP administration (48). Compared to similar studies of the same research group only using MSCs, addition of PRP seems to enable a more long-lasting lameness reduction (46-48).
MSC treatments seem to have a favorable clinical effect on lameness, joint pain and ROM. Although IA administration appears to be most promising, careful data interpretation is indicated since clinical lameness results are not always supported by objective gait analysis. Additional administration of HA and PRP may improve both clinical and pressure/force plate outcomes.

\section{Osteoarthritis Progression}

None of the studies on autologous and allogeneic MSC in dogs with naturally-occurring $\mathrm{OA}$ involving radiographic and CT imaging did show improvement of superficial bone changes 3 - 12 months post-treatment $(36,41,42,49,60)$. Nevertheless, throughout the study period, no radiographic OA progression was detected after IA application of autologous and allogeneic adipose tissue-derived MSCs $(41,49)$. In contrast, a study applying autologous adipose tissue-derived MSCs in combination with HA and patellar luxation surgery described a decrease in osteophytes and subchondral cystic lesions on radiographic evaluation (50).

Based on radiographic and CT imaging, it was concluded that therapeutically administered MSCs are probably unable to reverse OA-related superficial bone changes, however, they may be able to slow down or even stop OA progression. Additionally, it is important to realize that bone remodeling and thus radiographic changes take time, which might have been the limiting factor of some of these studies.

\section{Cartilage and Subchondral Bone Evaluation and Properties}

The presence of newly formed cartilage was visualized by macroscopic, microscopic and arthroscopic assessment and by MRI and SEM screening. In several model based studies evaluating autologous or allogeneic MSC usage, macroscopic and histologic evaluations, conducted between 8 and 24 weeks after 
MSC treatment, showed that experimentally created cartilage defects were (partially) filled with cartilage-like tissue, while the defects of the control groups were filled with fibrous tissue $(52-56,58,59)$. An arthroscopic evaluation and biopsy of an natural occurring $\mathrm{OA}$ defect showed cartilage regeneration 12 months after combined IA administration of allogeneic adipose tissue-derived MSCs and HA (39). In model-based studies on IA administration of allogeneic umbilical cord-derived and bone marrow-derived MSCs, respectively joint repair after 28 days and the presence of cartilage-like tissue after 28 weeks were reported based on MRI screening $(54,63)$. Li et al. (54) described cartilage-like tissue to be present after combined administration of MSCs and HA and after administration of HA alone, however, the cartilage-like tissue was thicker after the combined administration (54). To obtain a highly detailed presentation of the cartilage surface, SEM was applied by a model-based study on allogeneic umbilical cord-derived MSC usage. In the treated group, which was IA injected with MSCs, some small protuberances of cartilage on the articular surface were present 35 days post-treatment. The thickness of the new cartilage in the treated group was significantly higher than the thickness of the cartilage in the control group (63).

Cartilage production was assessed by a research group evaluating allogeneic transplantation of adipose tissue-derived MSCs in a cranial cruciate ligament transection study. The research group analyzed immunoreactivity against BrdU, a cell proliferating marker. The number of BrdU-positive cells, proliferating chondrocytes, was significantly decreased in the control group and significantly increased in the treatment groups. The increase of cell proliferation was most significant after a combined treatment of MSCs and PRP (51). Additionally, an immunohistochemistry test against caspase- 3 and poly adenosine diphosphate-ribose polymerase (PARP), which play a role in cell apoptosis and death, respectively, was conducted. The test results showed an increase of caspase-3- and PARPpositive cells in OA conditions and a decrease after MSC and/or PRP administration (51). Evaluations based on real-time PCR demonstrated an increase of extracellular matrix (ECM)-related genes (cartilage aggrecan and sex-determining region Y-related high mobility group-box [SOX]9) in the groups treated with MSCs, PRP or a combination. The increase of ECM-related genes was most prominent after the combination treatment (51).

The content of collagen and glycosaminocglycan (GAG), important components of hyaline cartilage, were evaluated by biochemical, spectrophotometric and immunochemical analyses. Biochemical evaluations performed by a research group evaluating autologous bone marrow-derived MSCs in OA models, demonstrated the GAG content of tissue-engineered cartilage to be $84.82 \% 6$ months after MSC enriched scaffold implantation. This reported percentage approaches the GAG content of normal cartilage in vivo (56). Spectrophotometric analyses of the ECM were performed by a cranial cruciate ligament transection study on allogeneic adipose tissue-derived MSCs and showed the collagen and GAG content to be significantly higher in the MSC treatment group than in the control group (51). Immunochemical analyses conducted by a model-based study on allogeneic bone marrow-derived MSC usage demonstrated that type II collagen formation was present in a group with MSC administration, but higher in another group with combined MSC and HA administration. The study suggested that combined usage of MSCs and HA could stimulate the regeneration of cartilage better than HA alone (54).

In model-based studies on autologous or allogeneic bone marrow-derived MSC application, implanting scaffolds in osteochondral defects, subchondral bone was assessed by microCT $(52,56,57)$. Qiang et al. (56) showed regularly formed mature trabecular bone 3 and 6 months after autologous MSC enriched scaffold treatment. Between control and treatment group, however, no significant differences on micro-CT assessment were found (56). On micro-CT evaluations of Duan et al. (52), large quantities of spongy bone were seen in the pours of the scaffold, both in the MSC enriched scaffold group and in the unseeded scaffold group (52). In contrast, in the study of Qiang et al. (57), micro-CT showed collapse of the high-load-bearing areas of the femoral head. Furthermore, the bone volume fraction (BVF) was lower in the treated than in the normal femoral heads (57).

Biomechanical analyses of cartilage and subchondral bone were conducted in model-based studies after autologous and allogeneic MSC administration (51, 56, 57). Biomechanical analyses applying autologous bone marrow-derived MSCs tested the stiffness of cartilage and osteochondral bone after MSC enriched scaffold implantation. 6 months after treatment, cartilage stiffness was $70.77 \%$ of normal cartilage and osteochondral bone stiffness was $74.95 \%$ of normal osteochondral bone. Thus, the newly formed cartilage and subchondral bone were only slightly softer than normal osteochondral tissue (56). In an allogeneic transplantation study, the focal compression strength of the affected articular surface was, compared to the control, significantly higher 5 months after administration of adipose tissue-derived MSCs and/or PRP. The highest strength was seen in the group combining MSCs and PRP (51). Reported stiffness of the high-load-bearing area of the femoral head 3 and 6 months after allogeneic bone marrowderived MSC enriched scaffold treatment was only $57.3 \%$ of normal stiffness. In this study, the scaffold failed to repair the created osteochondral defects (57).

Although study protocols are very variable, according to visual evaluations of the joint surface and assessments of cartilage production, MSC administration seems to be sufficient to cover chondral defects with cartilage-like tissue. The compositional and biomechanical characteristics of this newly formed cartilage are very similar to those of in vivo cartilage.

\section{MSC Homing}

MSC homing capacities were assessed by a model-based study on autologous bone marrow-derived MSCs, which performed a fluorescence analysis. GFP-labeled MSCs were detected in neocartilage 2 and 8 weeks after IA injection and thus confirmed MSC homing (55). These results are comparable to a similar model-based study in donkeys assessing the homing capacity of IA injected, GFP-labeled autologous bone marrow-derived MSCs. Fluorescence microscopy assessment confirmed the 
incorporation of GFP-labeled MSCs in the newly formed cartilage 1, 2 and 6 months post-treatment (69).

In contrast, in a study on IV injection of allogeneic adipose tissue-derived MSCs, MSCs labeled with a cell membrane dye were rarely detected in the synovial fluid (43). In a rabbit and horse study, however, homing of IV injected, respectively, autologous and allogeneic MSCs to places of tissue injury was confirmed $(70,71)$. Olsen et al. (43) reported pulmonary trapping, to early assessment of the synovial fluid, detainment in the synovial membrane and inadequate cell labeling as possible causes of their insufficient MSC homing detection (43).

Based on labeled MSCs detection studies, the principle of MSC homing after IA and IV administration seems to be promising for OA affected animals. In dogs, however, there is a discrepancy between study results after IA and IV MSC administration, which is probably a consequence of MSC distance to injury location. Otherwise, insufficient homing detection may be caused by unfitted assessment procedures. To uncover assessment failures, study results should be compared to clinical outcomes. For a better understanding of MSC homing in dogs, further research is warranted.

\section{Inflammation Biomarkers and Synovial Fluid Characteristics}

Evaluations of synovial fluid were performed in naturallyoccurring OA studies (31, 41-43). A decrease of chronic inflammation signs was detected 6 months after IA administration of autologous adipose tissue-derived MSCs. The numbers of leucocytes, neutrophils and mononuclear cells were within normal ranges, as was the color and viscosity of the synovial fluid (42). 12 months after autologous adipose tissue-derived MSC administration, however, another study did not detect significant synovial fluid changes (41). Also, after repeated IV injection of allogeneic adipose tissue-derived MSCs, no significant changes in OA biomarkers [prostaglandin E2 (PGE2) and matrix metalloproteinase-2 (MMP-2)] were found (43). After IA administration of equine peripheral blood-derived MSCs, analysis of synovial fluid, focusing on hemarthrosis and viscosity, remained unchanged in dogs suffering from naturally-occurring elbow OA (31).

Immunohistochemistry was applied in a cranial cruciate ligament transection study on allogeneic transplantation of adipose tissue-derived MSCs. Immunoreactivities in the cartilage tissue were determined against pro-inflammatory cytokines, tumor necrotic factor (TNF)- $\alpha$, cyclooxygenase (COX)-2, interleukin (IL)-1 $\beta$, inducible nitric oxide synthase (iNOS) and interferon (IFN)- $\gamma$, which significantly decreased in the treatment group compared to the control group (51).

In a model-based study, blood analyses after IA allogeneic umbilical cord-derived MSC treatment evaluated inflammatory factors such as IL-6, IL-7 and TNF- $\alpha$. No significant differences were detected 3 and 28 days after MSC treatment. At day seven, however, IL- 6 and TNF- $\alpha$ were significantly higher in the untreated group. At day fourteen, significantly lower levels of IL-6, IL-7 and TNF- $\alpha$ were detected in the treated group (63).
According to blood analyses and immunoreactivity evaluations of the cartilage surface, MSC administration appears to decrease levels of inflammatory factors. Assessments of synovial fluid, however, did not always show significant changes. Evaluation of the effect of MSCs on joint inflammation is challenging due to the variety of study designs and assessment protocols. The applied MSC type, for example, may influence study results. To better understand the effect of MSC treatments on joint inflammation, further investigation is indicated.

\section{Safety}

A safety assessment of IA and IV administration of MSCs was performed in some naturally-occurring OA studies, but important adverse events were not reported (31, 32, 36, 38, 42, $43,49,61,62)$. Only a few minimal side effects were noted by a minority of studies, such as worsening of lameness due to injection difficulties (46), mild skin allergy (44) and self-limiting joint distension $(39,61)$. Also, no MSC related negative effects were reported in model-based studies $(51-59,63)$.

\section{PROSPECTIVES AND CONSIDERATIONS OF MSC BASED OA THERAPIES}

Therapies based on MSCs seem to be promising for improvement in joint function and to heal cartilage defects in OA affected dogs. MSCs have the ability to forge a novel means to manage not only the clinical impact of OA in dogs, but also to modulate the disease. To overcome the practical difficulties of harvesting and cultivating autologous MSCs, "ready to treat" products based on allo- and xenotransplantation would be ideal for the practitioner. Moreover, to facilitate MSC administration, systemic delivery features are of researchers' interest.

In recent literature, suggestions have been made about other interesting stem cell related therapies besides MSCbased therapies. Induced pluripotent stem cells (iPSCs) can be obtained by reprogramming adult cells and have the ability to differentiate into any cell type of the body. Compared to MSCs, iPSCs have a greater differentiation potential and might be able to provide a higher stem cell yield per donor. However, iPSCs are described to be related to tumorigenesis, thus making them less safe to use and unfitted as an MSC alternative (72-74). To be able to consider iPSCs in future medicine, additional studies addressing safety and efficacy need to be performed. Alternative upcoming research has been directed toward cell-free stem cell related therapies. Cell-free stem cell related research focuses on the stem cell's paracrine factors, including extracellular vesicles (EVs), which seem to play an important role in its effectiveness. It is hypothesized that these EVs may be able to heal and prevent tissue damage with a lesser impact on the immune system. Nevertheless, before considering this MSC alternative, more studies need to be conducted according to mode of action, bioavailability and administration of EVs $(26,74)$. 


\section{CONCLUSION}

In current canine medicine, a variety of MSC studies were enrolled to encounter the problem of OA. These studies have were very different based on study design, e.g., MSC sources, MSC dosage, administration and efficacy evaluation. However, in general, studies on auto-, allo-, and xenotransplantation of MSCs show to be promising. Research assessing the effect of MSCs on naturally occurring OA mostly demonstrated positive clinical outcomes for all three transplantation types, e.g., a decrease of lameness and joint pain and an increase of joint function. The reported clinical signs were most significant after IA MSC administration. In contrast, results based on medical imaging, objective gait analysis and synovial fluid evaluations were more doubtful. Addition of PRP or HA might be able to improve treatment outcome compared to solo MSC administration. In accordance with studies on naturally occurring OA, model-based studies administering autologous or allogeneic MSCs described reduced lameness and joint discomfort. Moreover, a variety of research tools showed that the administration of MSCs, whether or not on a scaffold, did induce the formation of cartilage-like tissue. Both in naturally-occurring OA and model based studies, the limited adverse events were minor, indicating that MSCs can be applied safely in canine OA patients.

Although many promising results of MSC studies, careful data interpretation is indicated since the reported study set-ups

\section{REFERENCES}

1. Anderson KL, O'Neill DG, Brodbelt DC, Church DB, Meeson RL, Sargan D, et al. Prevalence, duration and risk factors for appendicular osteoarthritis in a UK dog population under primary veterinary care. Sci Rep. (2018) 8:1-12. doi: 10.1038/s41598-018-2 3940-z

2. Freitag J, Bates D, Boyd R, Shah K, Barnard A, Huguenin L, et al. Mesenchymal stem cell therapy in the treatment of osteoarthritis: reparative pathways, safety and efficacy-a review. BMC Musculoskelet Disord. (2016) 17:230. doi: 10.1186/s12891-016-1085-9

3. Johnston SA. Osteoarthritis: joint anatomy, physiology, and pathobiology. Vet Clin North Am Small Anim Pract. (1997) 27:699-723. doi: 10.1016/S0195-5616(97)50076-3

4. Rychel JK. Diagnosis and treatment of osteoarthritis. Top Companion Anim Med. (2010) 25:20-5. doi: 10.1053/j.tcam.2009.10.005

5. Sinusas K. Osteoarthritis: diagnosis and treatment. Am Fam Physician. (2012) 85:49-56.

6. Meeson RL, Todhunter RJ, Blunn G, Nuki G, Pitsillides AA. Spontaneous dog osteoarthritis-a One Medicine vision. Nat Rev Rheumatol. (2019) 15:27387. doi: 10.1038/s41584-019-0202-1

7. Houard X, Goldring MB, Berenbaum F. Homeostatic mechanisms in articular cartilage and role of inflammation in osteoarthritis. Curr Rheumatol Rep. (2013) 15:375. doi: 10.1007/s11926-013-0375-6

8. Necas J, Bartosikova L, Brauner P, Kolar J. Hyaluronic acid (hyaluronan): a review. Vet Med. (2008) 53:397-411. doi: 10.17221/1930-VETMED

9. Uthman I, Raynauld J, Haraoui B. Intra-articular therapy in osteoarthritis. Postgrad Med J. (2003) 79:449-53. doi: 10.1136/pmj.79.93 4.449

10. Wang C-T, Lin J, Chang C-J, Lin Y-T, Hou S-M. Therapeutic effects of hyaluronic acid on osteoarthritis of the knee: a meta-analysis of randomized controlled trials. JBJS. (2004) 86:538-45. doi: 10.2106/00004623-200403000-00012 are often very different which makes outcome evaluation and comparison challenging. Also, naturally-occurring OA studies are frequently lacking sufficient study populations and/or control groups, depreciating reported findings. To overcome these hurdles, standardization should be provided by future development of evidence based protocols. Such protocols should ensure strictly designed, blinded, randomized and controlled studies applying well-characterized MSCs (i.e., determination of cell viability, morphology, presence or absence of cell surface markers, differentiation and population doubling times) at considerable dosages. Moreover, further research investigating mode of action and safety will attribute to a better understanding of the possibilities of MSCs as an OA healing product.

\section{AUTHOR CONTRIBUTIONS}

Data was gathered by CB. The final paper was produced by $\mathrm{CB}$ under direct supervision of GP. Intellectual support was provided by JS, YS, and EB. All authors contributed to the article and approved the submitted version.

\section{ACKNOWLEDGMENTS}

Gratitude was directed toward GP, JS, YS, and EB for their intellectual support.

11. Kabiri A, Esfandiari E, Esmaeili A, Hashemibeni B, Pourazar A, Mardani M. Platelet-rich plasma application in chondrogenesis. Advanc Biomed Res. (2014) 3:138. doi: 10.4103/2277-9175.135156

12. Budsberg S.C. and Bartges JW, Nutrition and osteoarthritis in dogs: does it help? Vet Clin Small Anim Pract. (2006) 36:1307-23. doi: 10.1016/j.cvsm.2006.08.007

13. Gupta RC. Nutraceuticals in Arthritis. In: Nutraceuticals. Elsevier (2016). p. 161-76. doi: 10.1016/B978-0-12-802147-7.00013-9

14. Bauer JE. Responses of dogs to dietary omega-3 fatty acids. J Am Vet Med Assoc. (2007) 231:1657-61. doi: 10.2460/javma.231.11.1657

15. Mori TA, Beilin LJ, Omega-3 fatty acids and inflammation. Curr Atheroscler Rep. (2004) 6:461-7. doi: 10.1007/s11883-004-0087-5

16. de Bakker E, Van Ryssen B, De Schauwer C, Meyer E. Canine mesenchymal stem cells: state of the art, perspectives as therapy for dogs and as a model for man. Vet Q. (2013) 33:225-33. doi: 10.1080/01652176.2013.873963

17. Murray IR, Péault B. Q\&A: mesenchymal stem cells-where do they come from and is it important? BMC Biol. (2015) 13:99. doi: 10.1186/s12915-015-0212-7

18. Gupta PK, Das AK, Chullikana A, Majumdar AS. Mesenchymal stem cells for cartilage repair in osteoarthritis. Stem Cell Res Ther. (2012) 3:25. doi: $10.1186 /$ scrt116

19. Sasaki A, Mizuno M, Mochizuki M, Sekiya I. Mesenchymal stem cells for cartilage regeneration in dogs. World J Stem Cells. (2019) 11:254. doi: 10.4252/wjsc.v11.i5.254

20. Lo Monaco M, Merckx G, Ratajczak J, Gervois P, Hilkens P, Clegg P, et al. Stem cells for cartilage repair: preclinical studies and insights in translational animal models and outcome measures. Stem Cell Int. (2018) 2018:9079538. doi: 10.1155/2018/9079538

21. Ullah M, Liu DD, Thakor AS. Mesenchymal stromal cell homing: mechanisms and strategies for improvement. iScience. (2019) 15:421. doi: 10.1016/j.isci.2019.05.004

22. Jiang P, Mao L, Qiao L, Lei X, Zheng Q, Li D. Efficacy and safety of mesenchymal stem cell injections for patients with osteoarthritis: a 
meta-analysis and review of RCTs. Arch Orthop Trauma Surg. (2021). doi: 10.1007/s00402-020-03703-0. [Epub ahead of print].

23. Ma W, Liu C, Wang S, Xu H, Sun H, Fan X. Efficacy and safety of intra-articular injection of mesenchymal stem cells in the treatment of knee osteoarthritis: A systematic review and meta-analysis. Medicine. (2020) 99:49. doi: 10.1097/MD.0000000000023343

24. Song Y, Zhang J, Xu H, Lin Z, Chang H, Liu W, et al. Mesenchymal stem cells in knee osteoarthritis treatment: a systematic review and meta-analysis. $J$ Orthop Translat. (2020) 24:121-30. doi: 10.1016/j.jot.2020.03.015

25. Gugjoo MB, Amarpal A, Sharma GT. Mesenchymal stem cell basic research and applications in dog medicine. J Cell Physiol. (2019) 234:16779811. doi: $10.1002 /$ jcp. 28348

26. Mocchi M, Dotti S, Bue MD, Villa R, Bari E, Perteghella S, et al. Veterinary regenerative medicine for musculoskeletal disorders: can mesenchymal stem/stromal cells and their secretome be the new frontier? Cells. (2020) 9:1453. doi: 10.3390/cells9061453

27. DiMarino A, Caplan A, Bonfield T. Mesenchymal stem cells in tissue repair. Front Immunol. (2013) 4:201. doi: 10.3389/fimmu.2013.00201

28. Black LL, Gaynor J, Gahring D, Adams C, Aron D, Harman S, et al. Effect of adipose-derived mesenchymal stem and regenerative cells on lameness in dogs with chronic osteoarthritis of the coxofemoral joints: a randomized, double-blinded, multicenter controlled trial. Vet Ther. (2007) 8:272.

29. Tonchev $\mathrm{AB}, \mathrm{BeÅ} J$, Fiore $M, \operatorname{Ran} \ddot{A} \mathrm{i} \ddot{A}$ G, Chechi K, V. BojaniÄ, et al. Adipobiology of stem cell-based therapy: secretome insight. Biomed Rev. (2010) 21:57-63. doi: 10.14748/bmr.v21.47

30. Lin C-S, Lin G, Lue TF. Allogeneic and xenogeneic transplantation of adipose-derived stem cells in immunocompetent recipients without immunosuppressants. Stem Cells Dev. (2012) 21:27708. doi: $10.1089 / \mathrm{scd} .2012 .0176$

31. Daems R, Van Hecke L, Schwarzkopf I, Depuydt E, Broeckx SY, David M, et al. A feasibility study on the use of equine chondrogenic induced mesenchymal stem cells as a treatment for natural occurring osteoarthritis in dogs. Stem Cell Int. (2019) 2019:4587594. doi: 10.1155/2019/4587594

32. Tsai S-Y, Huang Y-C, Chueh L-L, Yeh L-S, Lin C-S. Intra-articular transplantation of porcine adipose-derived stem cells for the treatment of canine osteoarthritis: a pilot study. World J Transplant. (2014) 4:196. doi: 10.5500/wjt.v4.i3.196

33. Whitworth DJ, Banks TA. Stem cell therapies for treating osteoarthritis: prescient or premature? Vet J. (2014) 202:41624. doi: 10.1016/j.tvjl.2014.09.024

34. Wieczorek M, Abualrous ET, Sticht J, Álvaro-Benito M, Stolzenberg S, Noé F, et al. Major Histocompatibility Complex (MHC) Class I and MHC Class II Proteins: conformational plasticity in antigen presentation. Front Immunol. (2017) 8:292. doi: 10.3389/fimmu.2017.00292

35. Black LL, Gaynor J, Adams C, Dhupa S, Sams AE, R. Taylor, et al. Effect of intraarticular injection of autologous adipose-derived mesenchymal stem and regenerative cells on clinical signs of chronic osteoarthritis of the elbow joint in dogs. Vet Ther Res Appl Vet Med. (2008) 9:192-200.

36. Cuervo B, Rubio M, Sopena J, Dominguez JM, Vilar J, Morales M, et al. Hip osteoarthritis in dogs: a randomized study using mesenchymal stem cells from adipose tissue and plasma rich in growth factors. Int J Mol Sci. (2014) 15:13437-60. doi: 10.3390/ijms150813437

37. Guercio A, Marco Di P, Casella S, Cannella V, Russotto L, Purpari G, et al. Production of canine mesenchymal stem cells from adipose tissue and their application in dogs with chronic osteoarthritis of the humeroradial joints. Cell Biol Int. (2012) 36:189-94. doi: 10.1042/CBI20110304

38. Harman R, Carlson K, Gaynor J, Gustafson S, Dhupa S, Clement K, et al. A prospective, randomized, masked, and placebo-controlled efficacy study of intraarticular allogeneic adipose stem cells for the treatment of osteoarthritis in dogs. Front Vet Sci. (2016) 3:81. doi: 10.3389/fvets.2016. 00081

39. Kriston-Pál É, Czibula Á, Gyuris Z, Balka G, Seregi A, Sükösd F, et al. Characterization and therapeutic application of canine adipose mesenchymal stem cells to treat elbow osteoarthritis. Can J Vet Res. (2017) 81:73-78.

40. Marx C, Silveira MD, Selbach I, da Silva AS, Braga M, Camassola M, et al. Acupoint injection of autologous stromal vascular fraction and allogeneic adipose-derived stem cells to treat hip dysplasia in dogs. Stem Cell Int. (2014) 2014:391274. doi: 10.1155/2014/391274
41. Mohorič L, Zorko B, Ceh K, Majdič G. Blinded placebo study of bilateral osteoarthritis treatment using adipose derived mesenchymal stem cells. Slovenian Vet Res. (2016) 53:3

42. Nicpoń J, Marycz K, Grzesiak J, Smieszek A, Toker Z. The advantages of autologus adipose derived mesenchymal stem cells (AdMSCs) over the nonsteroidal anti-inflammatory drugs (NSAIDs) application for degenerative elbow joint disease treatment in dogs-Twelve cases. Kafkas Üniv Vet Fakültesi Dergisi. (2014) 20:345-50.

43. Olsen A, Johnson V, Webb T, Santangelo KS, Dow S, Duerr FM. Evaluation of intravenously delivered allogeneic mesenchymal stem cells for treatment of elbow osteoarthritis in dogs: a pilot study. Vet Comp Orthop Traumatol. (2019) 32:173-81. doi: 10.1055/s-0039-1678547

44. Shah K, Drury T, Roic I, Hansen P, Malin M, Boyd R, et al. Outcome of allogeneic adult stem cell therapy in dogs suffering from osteoarthritis and other joint defects. Stem Cell Int. (2018) 2018:7309201. doi: 10.1155/2018/7309201

45. Srzentić DraŽilov S, Mrkovački J, Spasovski V, Fazlagić A, Pavlović S, Nikčević G. The use of canine mesenchymal stem cells for the autologous treatment of osteoarthritis. Acta Vet Hung. (2018) 66:376-89. doi: 10.1556/004. 2018.034

46. Vilar JM, Batista M, Morales M, Santana A, Cuervo B, Rubio M, et al. Assessment of the effect of intraarticular injection of autologous adipose-derived mesenchymal stem cells in osteoarthritic dogs using a double blinded force platform analysis. BMC Vet Res. (2014) 10:143. doi: $10.1186 / 1746-6148-10-143$

47. Vilar JM, Cuervo B, Rubio M, Sopena J, Domínguez JM, Santana A, et al. Effect of intraarticular inoculation of mesenchymal stem cells in dogs with hip osteoarthritis by means of objective force platform gait analysis: concordance with numeric subjective scoring scales. BMC Vet Res. (2016) 12:223. doi: 10.1186/s12917-016-0852-z

48. Vilar JM, Morales M, Santana A, Spinella G, Rubio M, Cuervo B, et al. Controlled, blinded force platform analysis of the effect of intraarticular injection of autologous adipose-derived mesenchymal stem cells associated to PRGF-Endoret in osteoarthritic dogs. BMC Vet Res. (2013) 9:131. doi: 10.1186/1746-6148-9-131

49. Wits MI, Tobin GC, Silveira MD, Baja KG, Braga LMM, Sesterheim P, et al. Combining canine mesenchymal stromal cells and hyaluronic acid for cartilage repair. Genet Mol Biol. (2020) 43:1. doi: 10.1590/1678-4685-gmb-2019-0275

50. Yoon H-Y, Lee J-H, Jeong S-W. Long-term follow-up after implantation of autologous adipose tissue derived mesenchymal stem cells to treat a dog with stifle joint osteoarthrosis. J Vet Clin. (2012) 29:82-6.

51. Yun S, Ku S-K, Kwon Y-S. Adipose-derived mesenchymal stem cells and platelet-rich plasma synergistically ameliorate the surgicalinduced osteoarthritis in Beagle dogs. J Orthop Surg Res. (2016) 11:9. doi: 10.1186/s13018-016-0342-9

52. Duan X, Zhu X, Dong X, Yang J, Huang F, Cen S, et al. Repair of large osteochondral defects in a beagle model with a novel type I collagen/glycosaminoglycan-porous titanium biphasic scaffold. Mater Sci Eng C. (2013) 33:3951-7. doi: 10.1016/j.msec.2013. 05.040

53. Kazemi D, Shams A.senjan K, Dehdilani N, Parsa H. Canine articular cartilage regeneration using mesenchymal stem cells seeded on platelet rich fibrin: Macroscopic and histological assessments. Bone Joint Res. (2017) 6:98107. doi: 10.1302/2046-3758.62.BJR-2016-0188.R1

54. Li L, Duan X, Fan Z, Chen L, Xing F, Xu Z, et al. Mesenchymal stem cells in combination with hyaluronic acid for articular cartilage defects. Sci Rep. (2018) 8:1-11. doi: 10.1038/s41598-018-27737-y

55. Mokbel A, El-Tookhy O, Shamaa A, Sabry D, Rashed L, Mostafa A. Homing and efficacy of intra-articular injection of autologous mesenchymal stem cells in experimental chondral defects in dogs. Clin Exp Rheumatol. (2011) 29:275-84.

56. Qiang Y, Jiang P, Lu S-B, Guo Q-Y, Bin Z, Zhang L, et al. Evaluation of an extracellular matrix-derived acellular biphasic scaffold/cell construct in the repair of a large articular high-load-bearing osteochondral defect in a canine model. Chin Med J. (2011) 124:3930-8.

57. Qiang Y, Yanhong Z, Jiang P, Shibi L, Quanyi G, Xinlong M, et al. Xenoimplantation of an extracellular-matrix-derived, biphasic, 
cell-scaffold construct for repairing a large femoral-head high-loadbearing osteochondral defect in a canine model. Sci World J. (2014) 2014:127084. doi: 10.1155/2014/127084

58. Yamasaki S, Hashimoto Y, Takigami J, Terai S, Mera H, Nakamura H, et al. Effect of the direct injection of bone marrow mesenchymal stem cells in hyaluronic acid and bone marrow stimulation to treat chondral defects in the canine model. Regen Ther. (2015) 2:42-8. doi: 10.1016/j.reth.2015.10.003

59. Miki S, Takao M, Miyamoto W, Matsushita T, Kawano H. Intra-articular injection of synovium-derived mesenchymal stem cells with hyaluronic acid can repair articular cartilage defects in a canine model. J Stem Cell Res Ther. (2015) 5:2. doi: 10.4172/2157-7633.1000314

60. Bootcha R, Temwichitr J, Petchdee S. Intra-articular injections with allogeneic dental pulp stem cells for chronic osteoarthritis. The Thai J Vet Med. (2015) 45:131-9.

61. Cabon Q, Febre M, Gomez N, Cachon T, Pillard P, Carozzo C, et al. Long-term safety and efficacy of single or repeated intra-articular injection of allogeneic neonatal mesenchymal stromal cells for managing pain and lameness in moderate to severe canine osteoarthritis without antiinflammatory pharmacological support: pilot clinical study. Front Vet Sci. (2019) 6:10. doi: 10.3389/fvets.2019.00010

62. Kim SE, Pozzi A, Yeh J-C, Lopez-Velazquez M, Au Yong JA, Townsend S, et al. Intra-articular umbilical cord derived mesenchymal stem cell therapy for chronic elbow osteoarthritis in dogs: a double-blinded, placebo-controlled clinical trial. Front Vet Sci. (2019) 6:474. doi: 10.3389/fvets.2019.00474

63. Zhang B-y, Wang B-y, Li S-c, Luo D-z, Zhan X, Chen S-f, et al. Evaluation of the curative effect of umbilical cord mesenchymal stem cell therapy for knee arthritis in dogs using imaging technology. Stem Cell Int. (2018) 2018:1983025. doi: 10.1155/2018/1983025

64. Fraser JK, Wulur I, Alfonso Z, Hedrick MH. Fat tissue: an underappreciated source of stem cells for biotechnology. Trends Biotechnol. (2006) 24:1504. doi: 10.1016/j.tibtech.2006.01.010

65. Reich CM, Raabe O, Wenisch S, Bridger PS, Kramer M, Arnhold S. Isolation, culture and chondrogenic differentiation of canine adipose tissue-and bone marrow-derived mesenchymal stem cells-a comparative study. Vet Res Commun. (2012) 36:139-48. doi: 10.1007/s11259-012-9523-0

66. Johnson V, Webb T, Norman A, Coy J, Kurihara J, Regan D, et al. Activated mesenchymal stem cells interact with antibiotics and host innate immune responses to control chronic bacterial infections. Sci Rep. (2017) 7:1-18. doi: 10.1038/s41598-017-08311-4

67. Zhu C-j, Dong J-x, Jian L, Zhang M-j, Wang L-p, Ling L. Preliminary study on the mechanism of acupoint injection of bonemarrow mesenchymal stem cells in improving blood flow in the rat of hind limb ischemia. J Tradit Chin Med. (2011) 31:241-5. doi: 10.1016/S0254-6272(11)60050-2
68. Kim YS, Kwon OR, Choi YJ, Suh DS, Heo DB, Koh YG. Comparative matched-pair analysis of the injection versus implantation of mesenchymal stem cells for knee osteoarthritis. Am J Sports Med. (2015) 43:273846. doi: 10.1177/0363546515599632

69. Mokbel AN, El Tookhy OS, Shamaa AA, Rashed LA, Sabry D, El Sayed AM. Homing and reparative effect of intra-articular injection of autologus mesenchymal stem cells in osteoarthritic animal model. BMC Musculoskelet Disord. (2011) 12:259. doi: 10.1186/1471-2474-12-259

70. Mund SJ, Kawamura E, Awang-Junaidi AH, Campbell J, Wobeser B, MacPhee DJ, et al. Homing and engraftment of intravenously administered equine cord blood-derived multipotent mesenchymal stromal cells to surgically created cutaneous wound in horses: a pilot project. Cells. (2020) 9:1162. doi: $10.3390 /$ cells 9051162

71. Ueda S, Shimasaki M, Ichiseki T, Ueda Y, Tsuchiya M, Kaneuji A, et al. Prevention of glucocorticoid-associated osteonecrosis by intravenous administration of mesenchymal stem cells in a rabbit model. BMC Musculoskelet Disord. (2017) 18:480. doi: 10.1186/s12891-017$1837-1$

72. Attwood SW, Edel MJ, iPS-cell technology and the problem of genetic instability-Can it ever be safe for clinical use? J Clin Med. (2019) 8:288. doi: $10.3390 /$ jcm 8030288

73. Jiang S, Tian G, Li X, Yang Z, Wang F, Tian, et al. Research progress on stem cell therapies for articular cartilage regeneration. Stem Cell Int. (2021) 2021:8882505. doi: 10.1155/2021/8882505

74. Taheri B, Soleimani M, Fekri Aval S, Esmaeili E, Bazi Z, Zarghami N. Induced pluripotent stem cell-derived extracellular vesicles: a novel approach for cell-free regenerative medicine. J Cell Physiol. (2019) 234:845564. doi: $10.1002 /$ jcp. 27775

Conflict of Interest: JS is employed with Boehringer-Ingelheim Animal-health (BI-AH) and author GP is employed by Global Stem cell Technology (GST).

The remaining authors declare that the research was conducted in the absence of any commercial or financial relationships that could be construed as a potential conflict of interest.

Copyright (๐ 2021 Brondeel, Pauwelyn, de Bakker, Saunders, Samoy and Spaas. This is an open-access article distributed under the terms of the Creative Commons Attribution License (CC BY). The use, distribution or reproduction in other forums is permitted, provided the original author(s) and the copyright owner(s) are credited and that the original publication in this journal is cited, in accordance with accepted academic practice. No use, distribution or reproduction is permitted which does not comply with these terms. 